ENABLING SOCIAL ENTERPRISE THROUGH REGULATORY INNOVATION: A CASE STUDY FROM THE UNITED KINGDOM

\author{
A Thesis \\ submitted to the Faculty of the \\ Graduate School of Arts and Sciences \\ of Georgetown University \\ in partial fulfillment of the requirements for the \\ degree of \\ Master of Public Policy \\ in Public Policy
}

By

Nicholas Edward Florek, B.B.A

Washington, DC

April 13, 2011 
Copyright 2011 by Nicholas Edward Florek

All Rights Reserved 


\title{
ENABLING SOCIAL ENTERPRISE THROUGH REGULATORY INNOVATION: A CASE STUDY FROM THE UNITED KINGDOM
}

\author{
Nicholas E. Florek, B.B.A. \\ Thesis Advisor: Gillette Hall, Ph.D.
}

\begin{abstract}
Social enterprise, broadly defined as the innovative use of resources to achieve social goals, is a new and emerging part of the global economy that has the potential to address pressing social problems ranging from education to health care. It is a growing component of what is often referred to as the third sector; the part of the economy that encompasses organizations that are neither governmental nor for-profit business institutions. Within the last two decades, governments have begun to take note of this trend and make policy changes to support the sustained emergence of these enterprises. One policy option that has recently emerged in Europe and the United States is the creation of a separate regulatory framework for social enterprises via new forms of legal organization. This paper uses the United Kingdom as a case study to explore the effectiveness of one new type of social enterprise legal organization, the community interest company. By analyzing data collected from the UK's National Survey of Third Sector Organisations in 2009 , this paper examines if organizations operating as community interest companies exhibit some of the characteristics that policy makers intended to foster when drafting the new legislation. Do community interest companies have easier access to a variety of funding sources and thus utilize a wider range? Also, are community interest companies relying on earned income as a primary and major source of funding as the legislation was intended to ease restrictions on market activities? The hypothesized relationship is positive in both of these cases
\end{abstract}


but results of the analysis support only a positive relationship between community interest companies and prioritization of earned income. Community interest companies are more likely to rely on earned income for at least $50 \%$ of their funding than any other organizational form among third sector organizations. 
The research and writing of this thesis could not have been possible without the tremendous support of my thesis advisor Dr. Gillette Hall and the students in my thesis workshop.

I would also like to give special thanks to Dr. Steven R. Smith and Dr. Tessa Hebb for their invaluable feedback regarding the content of my research as well as Tom Neeley and Natalie Rico for their excellent editorial eyes.

Many thanks, Nicholas E. Florek 


\section{TABLE OF CONTENTS}

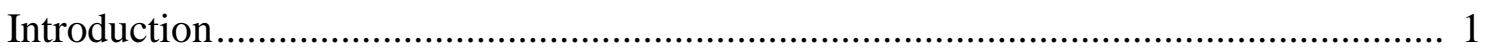

Defining and Encouraging Social Entrepreneurship............................................. 3

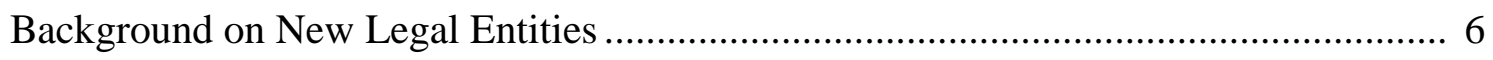

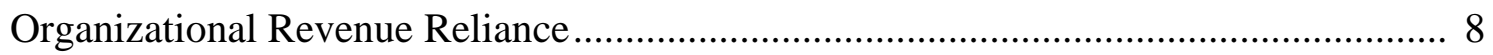

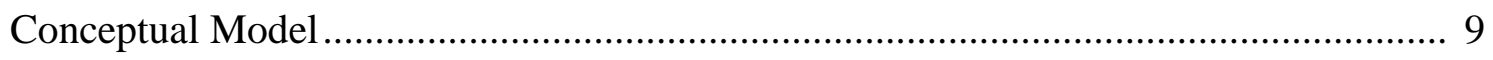

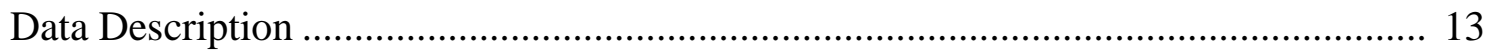

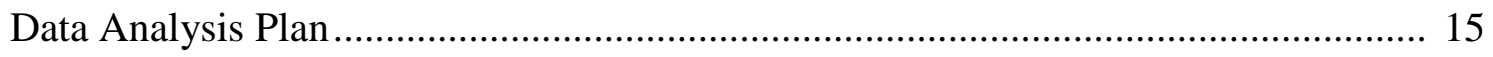

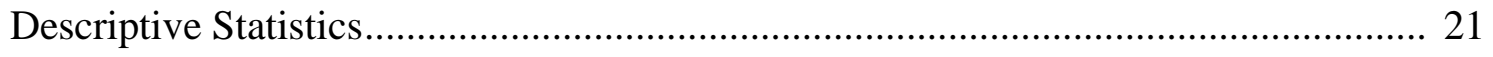

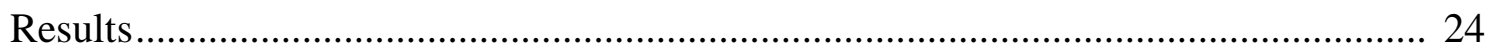

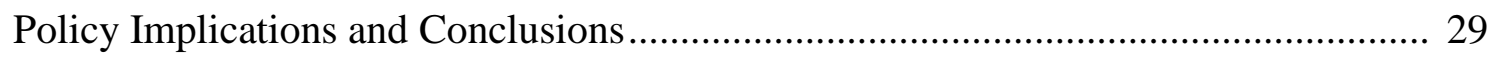

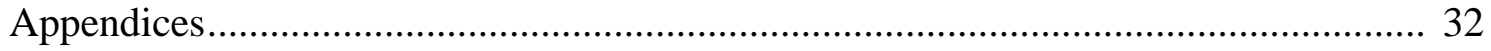

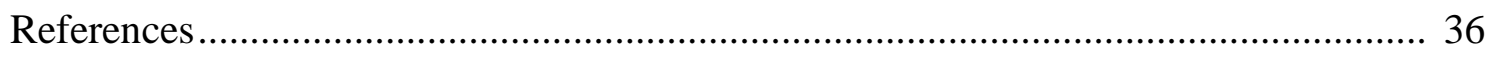




\section{INTRODUCTION}

An innovative idea, if cultivated appropriately, has the power to significantly impact pressing social problems. For example Teach for America, conceived by Wendy Kopp, now employs 8,200 corps members in underperforming schools across 39 separate regions of the United States. Far across the globe, the Grameen Bank of Bangladesh and Muhammad Yunus ${ }^{\mathrm{a}}$ received the Nobel Peace Prize in 2006 for efforts to "create economic and social development from below (The Nobel Foundation, 2006)." Since the 1970’s Grameen has provided over $\$ 8.7$ billion in loans to the poor. On the surface, these two organizations appear to be very different. One turns recent college graduates into teachers in low-income communities in the United States and the other provides micro-credit loans, operating primarily in the developing world. However, they both have one key aspect in common. They are excellent examples of the potential impact that social entrepreneurship can have in addressing difficult social problems. In fact, both Wendy Kopp and Muhammad Yunus have been recognized by the organization Ashoka as exemplary social entrepreneurs.

As early as the 1970's, the term "entrepreneur" was plucked from the business world and adapted to be used to describe management focused on solving social problems in addition to profit maximization (Banks, 1972). What exactly constitutes a social entrepreneur (and social entrepreneurship more broadly) depends on who one may ask, but these individuals generally operate in what is often referred to as the third sector; the part of the economy that encompasses

\footnotetext{
a This paper acknowledges the current controversy surrounding Muhammad Yunus and the Grameen Bank. However, this should not detract from the original power of the idea of microfinance and the scale to which it has currently reached.
} 
organizations that are neither governmental nor for-profit business institutions. These individuals mobilize resources in innovative ways towards solving a particular social goal that may not currently be adequately addressed by existing organizational structures and paradigms. The organizations formed and run by social entrepreneurs are referred to as social enterprises and can take a broad variety of forms including both nonprofit and business like entities. In general, however, there has been some convergence on the idea that a social enterprise is an organization that has a primary purpose of addressing a particular social problem through innovation and may also be at least partly financially self-sustaining (SBA Office of Advocacy, 2007; UK Office of Third Sector, 2006).

Recently governments worldwide have recognized the opportunity for social enterprises to tackle problems traditionally addressed by governments, and multilateral organizations. They have taken steps toward supporting these enterprises which have included initiatives such as the creation of the Social Enterprise Unit of the UK government in 2002, the White House's Office of Social Innovation in 2009, and capital funds in Europe and the United States designed to specifically support emerging social enterprises. What may be most interesting and promising however is the effort underway in many countries to create a new legal entity identifying social enterprises as distinct types of organizations that are neither profit maximizing businesses, nor typical nonprofit organizations. This new legal recognition is intended to allow social enterprises to bypass some of the regulatory burden associated with nonprofit organizations, provide flexibility, create a more standardized industry, and allow for more rigorous quantitative assessment of the performance of social enterprises. Such legal entities have been created in 
Italy, Portugal, Spain, Greece, and Britain among other European countries as well as a handful of U.S. states.

The case of Britain is particularly interesting given the general support for social enterprise to play an important part in society, and the government's attempt to foster and measure the effectiveness of its third sector. In fact, it is perhaps the only country in the world to conduct a comprehensive assessment of the state of the third sector and the level of support they receive from the government. Using data from the National Survey of the Third Sector Organizations (2009), this paper examines whether a new legal entity in the United Kingdom, the community interest company (CIC), has been effective in reducing the challenges faced by social enterprises organized under more traditional legal structures. Specifically, it analyzes whether the easier access to multiple capital sources leads community interest companies to utilize a more diverse array of funding sources. It also examines if community interest companies prioritize earned-income as their primary revenue source given that the legislation provides a specific mechanism profit to be used for a social purpose. The results will provide insight to policymakers in other countries as they consider passing similar legislation.

\section{DEFINING AND ENCOURAGING SOCIAL ENTREPRENEURSHIP}

The first mention of the term social entrepreneur in academic literature arises in Banks (1972) who used the term in an analysis of different approaches to management with a focus on achieving social goals. In the remainder of the decade, however, the term was scarcely mentioned again except for work by Etzioni (1973) that discusses the emergence of a sector at 
the intersection of the public and private sectors. While he does not explicitly use the term "social entrepreneur" or "social entrepreneurship," the concept he discusses very closely aligns with contemporary definitions. In the 1980's, Bill Drayton founded the organization Ashoka whose mission includes creating a global environment that allows social entrepreneurs to thrive (Ashoka, n.d.) and the concept of social entrepreneurship started to gain both popular and academic traction. Since that time, there has been a growing recognition of these third sector enterprises, and in parallel, a body of primarily qualitative research that has focused on defining social enterprise and entrepreneurship as well as examining how it fits among existing organizational structures (Nicholls, 2006). Further research has looked at the policy and institutional mechanisms that encourage successful social entrepreneurship and social enterprise creation (SBA Office of Advocacy, 2007, UK Strategy Unit, 2002, UK Office of Third Sector, 2006).

Social entrepreneurship and social enterprise specifically have been described in a number of different ways, which tend to carry the same overall theme. For example, Hulgard (2010, p 4) characterizes social entrepreneurship as "the creation of a social value that is produced in collaboration with people and organizations from the civil society who are engaged in social innovations that usually imply economic activity" while Reis (1999, p 15) defines it as “applying business expertise and market-based skills in the nonprofit sector.” Dees (2001, p 4) provides a more nuanced definition, suggesting that social entrepreneurs play the role of change agents in the social sector through "adopting a mission to create and sustain social value; recognizing and pursuing new opportunities; engaging in a process of continuous innovation, adaptation, and learning; acting boldly without being limited by resources; and exhibiting 
heightened accountability to the constituencies served and for the outcomes created".

Additionally the Department of Trade and Industry in the UK $(2002, \mathrm{p} 7)$ characterize social enterprise as a "business with primarily social objectives whose surpluses are principally reinvested for that purpose in the business or in the community, rather than being driven by the need to maximize profit for shareholders or owners.” And the White House's Office of Social Innovation and Civic Participation has as its mission a "bottom-up, innovative, and resultsoriented community solutions agenda (The White House: About SICP, n.d.). As one can see, even without one solid definition, it is clear that a social enterprise is a type of entity that has a primary social purpose, often generates revenue, and is innovative in the means by which it achieves its goals.

Given the positive effects that social enterprises can often have on society, governments have undertaken efforts to identify what types of policies and institutional changes can help support the emergence of such organizations. The United States Small Business Administration, in its 2007 report to the President, uses case studies to determine some of the most effective ways that government can encourage social entrepreneurship. These include encouraging social innovation through seed funding, creating an enabling environment by removing policy barriers, rewarding performance with government purchase or additional funding, scaling success with government help, and producing knowledge by ensuring organizations have reliable and accurate data. The report also cites how states such as Louisiana have created a state office specifically dedicated to encouraging social entrepreneurship. The Social Enterprise Action Plan (2006) released by the UK government echoes many of these objectives. Specifically it identifies the government as playing an enabling role by fostering a culture of social enterprise, ensuring the 
right information and advice are available to those running social enterprises, facilitating access

to appropriate finance, and enabling social enterprises to work with the government. Mandelson (1997) also notes how the New Labour Party has supported social enterprise by drawing on the tradition of community development and associated action aimed at inclusive individual and community empowerment.

\section{BACKGROUND ON NEW LEGAL ENTITIES}

One specific mechanism that legislative bodies have begun to support more frequently is the creation of separate legal status for social enterprises. This trend has roots dating back to the early 1990's in Italy. In an effort to start supporting new forms of cooperatives that had formed to serve the unmet needs of broad community groups, the Italian Parliament passed legislation creating a new legal entity called a "social co-operative." Since that time, other countries in Europe have followed suit, albeit in their own unique ways. Belgium created the "social purpose company" legal framework in 1996 as a classification that existing business corporations can adopt if they define a profit allocation policy in accordance with a social purpose. Portugal created the "social solidarity co-operative" in 1997 to support organizations with objectives of fostering integration of vulnerable groups, such as children, people with disabilities, and socially disadvantages families and communities (Defourny and Nyssens, 2009). Spain and Greece created "social initiative co-operatives" and "limited liability social co-operatives" respectively in 1999, and France passed a law in 2002 creating the "collective interest co-operative society." To date, these frameworks have seen mixed results. The "social co-operative" framework was 
utilized by over 7,300 organizations in Italy in 2005, yet the new structures in France and Belgium have seen little success (Defourney and Nyssens, 2009).

Perhaps the most successful effort, as evidenced by its rapid uptake and popular support, to create a supportive legal framework for social enterprises is the community interest company (CIC) created by the British Parliament in 2005. At that time, the UK government estimated that there were 55,000 social enterprises in the country that represented a contribution of $£ 8.4$ billion to national GDP (UK Office of Third Sector, 2005). Traditionally, social enterprises in the UK were organized either as unincorporated charities, companies limited by guarantee (CLG), or industrial and provident societies (IPS). However, these forms of organization each have certain restrictions that present challenges to social enterprises. Among the main difficulties from these structures include restrictions on commercial activities and high regulatory burdens for charities, lack of asset protection and limits on equity financing for both CLG's and IPS's, expensive registration for IPS's, and weak social enterprise branding within all of these frameworks ${ }^{\mathrm{b}}$ (UK Cabinet Office: Strategy Unit, 2002). In light of these pitfalls, the UK government presented a case for creating a new legal entity specifically designed for social enterprises. In 2005, this came to fruition when the Companies (Audit, Investigations and Community Enterprise) Act formally created the Community Interest Company. Among other benefits, the Community Interest Company was intended to be a more flexible form of organization, easier to register, allow access to a wide range of debt and equity funding sources, and facilitate socially motivated profit-making activity. As of December 2010 there have been 4,396 (CIC regulator) organizations registered as CIC's in the United Kingdom.

\footnotetext{
${ }^{\mathrm{b}}$ For a more in-depth description of these legal frameworks please reference appendix A
} 


\section{Organizational Revenue Reliance}

As one of the aforementioned intended benefits of the CIC structure is to allow access to a wide range of debt and equity funding sources, it is important to consider what other determinants may influence the revenue sources an organization relies upon. The body of literature examining revenue reliance of nonprofit organizations provides a solid base to build upon. One body of work in this area focuses mainly on the advantages and disadvantages that accrue to nonprofits as the result of diverse revenue streams (Thompson, 1967; Evans and Archer, 1968; Galbraith, 1977; Pfeffer and Salancik, 1978; Fuller and Farrell 1987; Chabotar 1989). Most theories suggest that nonprofits find many advantages in developing multiple revenue streams including the probability of remaining financially viable by reducing instability (Evans and Archer, 1968; Fuller and Farrell, 1987). Another body of work focuses on identifying the determinants of such diversification. Chang and Tuckman (1994) provide a theoretical foundation for measuring revenue origins and diversification, determining that the activities of a nonprofit, as well as its financial position, are determinants of the concentration of an organization's revenue sources. Geographic locations, tax level, membership in an association, maturity, and size have also been found to affect revenue origins and diversification (Brooks, 2000; Derryck and Abzug, 2002; Kimberly, Miles, and Associates, 1980; Bowman, Keating, and Hager, 2007). In addition, further work by Okten and Wiesbrod (2000) demonstrates that revenue generated from government grants or commercial activity does not crowd out private donations. The most recent research, however, comes from Young, Fischer, and Wilsker (2010) who show that sources of revenue depend on the public or private nature of 
the benefit provided and that the proportion of revenue generated from earned program revenue is highest for organizations that provide private benefits.

\section{CONCEPTUAl Model}

What determines which and how many revenue sources an organization taps into to finance its operations? This paper examines whether the creation of a new organizational legal form is sufficient to provide social enterprises access to more funding sources than existing structures as well as facilitate using earned revenue as a primary means of supporting their social goals. Thus, it is important to identify what other factors influence organizational decisionmaking and behavior when selecting funding sources. Since historically many social enterprises have operated under the legal framework of traditional nonprofit organizations, it reasons that the same theoretical determinants of revenue diversification and reliance on earned income for nonprofits can be applied more broadly to all social enterprises regardless of legal status.

Broadly speaking, past research has pointed to three overarching factors that tend to influence how nonprofit organizations decide upon where to obtain their financing: (1) the nature of the organization's activity, (2) characteristics of the organization itself, and (3) characteristics of the environment in which the organization operates (See Chart 1). No complete model has been constructed that includes all possible factors encompassed by these categories, but researchers have identified certain key determinants within each category that appear to have a relationship with the type and number of revenue sources an organization relies upon (Chang and Tuckman, 1994; Fischer et al., 2010). 
The nature of an organization's activities has been linked to how that organization obtains revenue in two manners. In the first manner, type of activity was shown by Chang and Tuckman (1994) to have a significant relationship with diversification of revenue sources. They posit three reasons for this relationship. First, certain activities by their nature are easier to finance from multiple sources. The example cited is a cancer clinic which can rely on revenue from patients, donations, government, and community organizations. This is compared to an environmental group which may be restricted to membership dues and governmental grants. Second, they believe that specific donors, governments, and consumers prefer to fund some activities over others. Lastly, administrators of certain nonprofits may simply have access to a broader range of sources than others. The second manner in which an organization's activities have been linked to revenue sources is through the public or private nature of the good provided. Fischer et al. (2010) show that nonprofits that provide goods of an economically private nature tend to rely more on earned program revenues than nonprofits that provide goods of an economically public nature. This makes sense as private goods are easier for individuals to value and thus they are more willing to pay for such services.

The characteristics of an organization itself have been theoretically linked to revenue reliance via organizational size, financial position, and maturity. Bowman, Keating, \& Hager (2007) propose that larger organizations have more resources in reserve funds, endowments, and infrastructure. Thus, the incentive to diversify revenue sources or generate new income streams is less than smaller organizations. Chang and Tuckman (1994) demonstrate a positive relationship between financial position and revenue diversification, suggesting that more profitable organizations have more diversified revenue sources. However, the causal nature of 
the relationship is not entirely clear and warrants further investigation. Lastly, the maturity or age of an organization has been linked to reliance on specific revenue sources in two competing theoretical views. The first is that newer nonprofits may be more likely to rely on a variety of donor and public funds as they are often piecing together resources to stay afloat (Chambre \& Fatt 2002; Young, 1985). The second view suggests an opposite relationship, given that a mature nonprofit is led by an experienced manager who consciously makes the decision to differentiate resources (Kimberly et al., 1980).

Environmental characteristics include those aspects of the operating environment that could potentially influence decision-making by organizations when identifying sources of revenue. Fisher et al. (2010) propose a relationship with geographic location which may reflect differences in needs for services as well as policy choices such as tax levels. Locations that are poorer economically tend to receive a greater amount of public funding as these areas may be a priority for redistributive aspects of government policy (Clifford et al., 2010). Taxes also have the possibility to encourage or discourage private donations depending on how the tax code is structured. Additional research by Derryck \& Abzug (2002) has suggested that membership in a regional or national association may reduce the funding risk a nonprofit faces and furthermore it's incentive to diversify. 


\section{Chart 1: The Determinants of Where an Organization Obtains Financing}

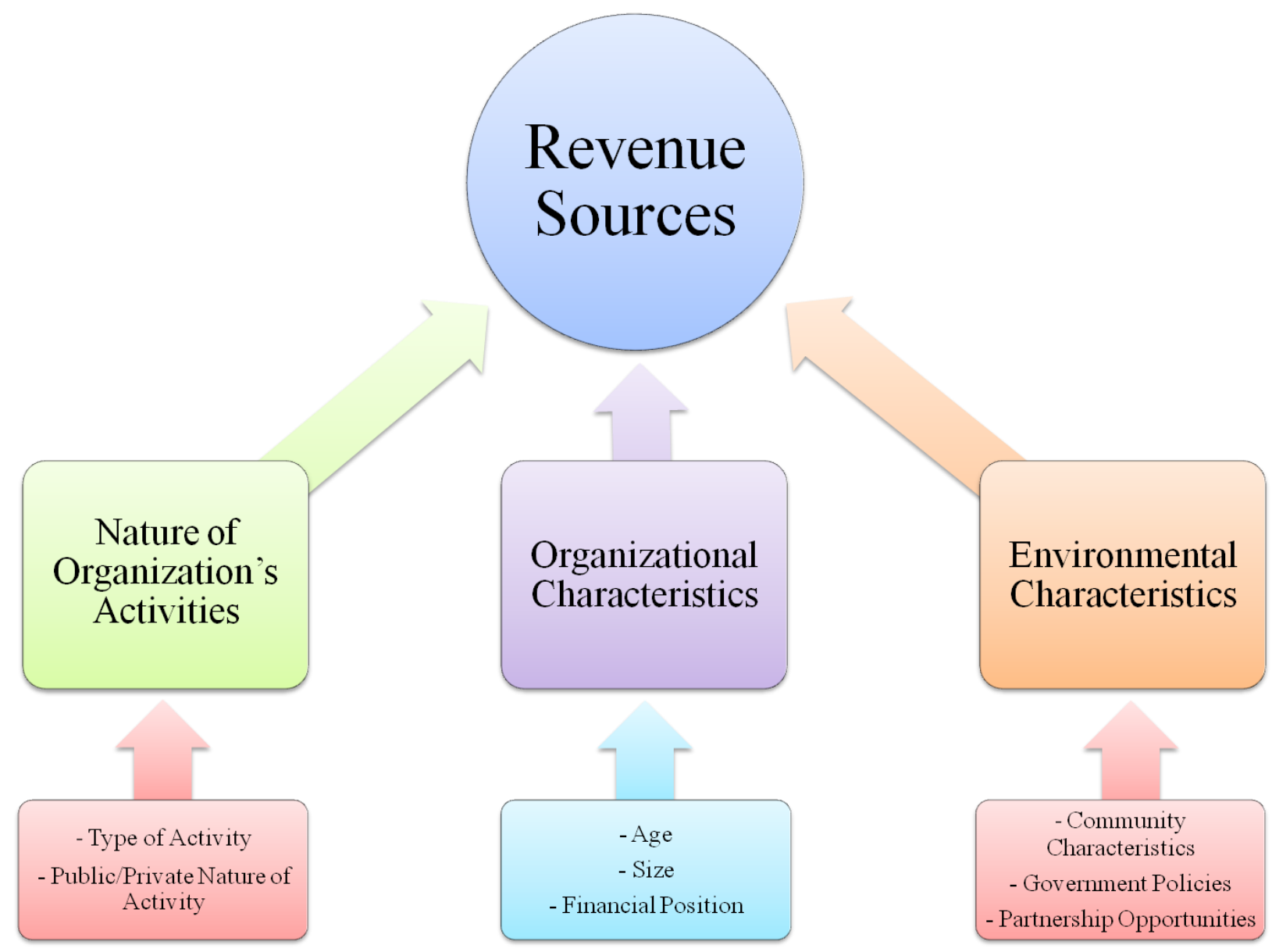

Note: There determinants of which revenue sources an organization decides to rely upon to pursue its mission can be divided into three broad categories: (1) the nature of the organization's activities, (2) characteristics of the organization itself, and (3) characteristics of the external environment in which it operates. These categories can be further broken down into specific attributes that can be identified for any particular organization under observation.

Thus, when identifying the effect of a new organizational legal form on revenue diversification and prioritization of earned income for social enterprises, the above factors must also be considered. While the strength and nature of these relationships are not always theoretically clear, their potential impact could influence the robustness of any other proposed relationship with organizational form. This paper proposes specifically that the community 
interest company organizational form is a predictor of what type and how many revenue sources an organization relies upon. Therefore, a complete conceptual model includes organizational legal form as a key component of the regulatory environment that an organization operates in. This factor, combined with other environmental characterizes, organizational characteristics, and the nature of activity define fully the potential influencing factors that determine where organizations obtain their funding. The hypotheses to be tested are thus as follows:

1.) Community Interest Companies utilize more sources of revenue than traditional third sector organizational structures.

2.) Community Interest Companies are more likely to prioritize earned income as their primary source of revenue than traditional third sector organizational structures.

\section{DATA DESCRIPTION}

The dataset used to examine the proposed hypotheses is the National Survey of Third Sector Organisations (TSO's) commissioned by the UK Office of the Third Sector, distributed and completed in 2009. The survey was distributed to a representative sample of 104,391 third sector organizations in the 149 upper-tier local authorities (delineation for local governments) in England. Within each local authority, the sample was stratified by organization type (Charity, Community Interest Company, Company Limited by Guarantee, or Industrial and Provident Society) and by income. In those authorities with relatively fewer TSO's, the survey was distributed to all organizations in the sampling frame in order to achieve the targeted number of 
respondents. In authorities with relatively more abundant TSO's, the survey was only distributed to a representative portion of those in the sampling frame.

Overall, a response was received from a total of 48,939 organizations (47\% response rate). A detailed analysis of response rate by a number of identifying factors is included in the original survey technical report. The analysis maintains the representativeness of the sample by showing that response rate did not vary greatly along any one dimension. The only noticeable exceptions are by location and organization type. TSO's in London maintained a response rate of $37 \%$ compared to a high of $53 \%$ for the South West region. In addition, registered charities tended to respond with more frequency (52\%) than other organizational forms (IPS: 38\%, CLG: 29\%, CIC: $33 \%$ ). Since the analysis in this paper is designed to show a relationship between CIC's and dependent variables of interest at the national level, any weighting adjustments by location are not necessary. Furthermore, the difference in response rate by organizational type suggests that the sample includes proportionally more charities than may be true of the population as a whole. However, due to potential implications of non-response bias and the unlikelihood that this will significantly affect results, no weighting along this dimension is performed either.

The original purpose of the survey was to determine the extent to which local statutory or governmental institutions supported the activities of the surveyed organizations and contributed to a thriving third sector. A national indicator based on a subset of survey questions was created to measure the extent that local government and its partners support the successful operation of independent third sector organizations. In addition, the survey also provides a wealth of comprehensive information about third sector organizations that has not been compiled in such a 
complete fashion previously. It asked questions regarding organizational size, structure, role, funding sources, target groups, and scope, among other things on which this paper capitalizes.

\section{Data Analysis Plan}

This paper uses two regressions techniques to allow for analysis of the proposed research question. The first regression is an ordinary least squares (OLS) regression that estimates the number of revenue sources an organization relies upon and the second is a probit specification to determine the probability that an organization relies upon earned income as its primary revenue source. In both cases, the main independent variable of interest is organizational legal form. To determine the effect of registering as a community interest company on each of the dependent variables, the following econometric models are used:

H1:

Number of Revenue Sources $=\boldsymbol{B}_{0}+\boldsymbol{B}_{1}$ Organizational Legal Form $+\boldsymbol{B}_{2}$ Main Area of Work $+\beta_{3}$ Role of Organization $+\beta_{4}$ Geographic Deprivation Level $+\beta_{5}$ Scope of Work + $B_{6}$ Adequacy of Financial Resources $+B_{7}$ Annual Income $+B_{8}$ Registration Year $+u$

H2:

$\mathbf{P}($ Earned Income Primary Source $=1 \mid x)=\boldsymbol{\beta}_{0}+\boldsymbol{\beta}_{1}$ Organizational Legal Form $+\boldsymbol{B}_{2}$ Main Area of Work $+\boldsymbol{B}_{3}$ Role of Organization $+\boldsymbol{B}_{4}$ Geographic Deprivation Level $+\beta_{5}$ Scope of Work $+\beta_{6}$ Adequacy of Financial Resources $+\beta_{7}$ Annual Income $+\beta_{8}$ Registration Year $+u$ 
An OLS regression is used in the first case because the number of revenue sources an organization relies upon can be modeled as a continuous variable ranging from one to nine depending on the survey response. The probit specification is appropriate in the second case because earned income is either regarded as the primary source of revenue or it is not. This model allows one to analyze such a dichotomous dependent variable to determine the probability that an organization will prioritize earned income as its primary source. A complete discussion of the two dependent variables, independent and control variables, as well as potential econometric issues follows.

\section{Population Specification and Missing Data}

About $72 \%$ of the organizations that responded to the survey did not answer all of the questions. However, $80 \%$ answered at least 32 of the 35 total questions. Since the questions that organizations failed to answer tended to relate to organizational income and its sources, missing data could have a potential impact on econometric results if not accounted for appropriately. For purposes of eliminating any potential item non-response bias, 7,045 organizations who did not report their income are removed from the sample used in analysis. This reduces the sample from 48,939 organizations to 41,894 . Summary statistics comparing the set of organizations with missing data to the entire sample do not identify any particular dimension along which organizations not reporting income seem to cluster. However, a regression of missing income on the dependent variables of interest does display a significant relationship. This suggests that there may be an unknown characteristic of the organizations who did not report income that may 
bias results. In light of this, these organizations were dropped from the sample and any results should be interpreted in light of this fact.

The other source of missing data came from registration year which was only available for registered charities. Since registration year data is banded in the data set, the last band (2005 - 2008) could be applied to CIC's as they did not exist prior to 2005. This left 7,976 observations missing registration year data which were all of the CLG and IPS organizational legal form. Given the correlation between missing registration year data and organizational legal form, registration year is not included as a control variable in the primary regressions. To account for the potential implications of an organization's age on the dependent variables, a separate regression is run comparing CIC's to registered charities only for organizations registering in the $2005-2008$ band.

\section{Dependent Variables}

The first dependent variable analyzed, number of revenue sources, is derived from the survey question that asks, "Does your organization receive income from any of the sources listed below?" Organizations were given nine different options plus an option for "None of these" or "Don't know." Based on the number of sources an organization selects, a continuous variable was constructed that ranges from one to nine. The last two options are considered missing data and the appropriate imputation method is performed. Organizations that selected "None of these," "Don’t know," or did not answer were assigned a zero. 
The second dependent variable, earned revenue, is a dichotomous categorical variable that equals 1 if an organization states that earned revenue accounts for $50 \%$ or more of total income and 0 if an organization states otherwise. This is derived from the survey question which states, "If your organization earns income from contracts or from trading, do these sources account for $50 \%$ or more of your total income when combined?"

\section{Independent Variable of Interest}

Organizational Legal Form - This is the main independent variable of interest. Organizations in the dataset are classified as either registered charities, companies limited by guarantee, community interest companies, or industrial \& provident societies. For purpose of analysis, a separate dummy variable is created for companies limited by guarantee, community interest companies, industrial \& provident societies, and charities. The hypothesized relationship is that community interest companies will have greater revenue diversification and also prioritize earned income over all three other types of organizational legal form.

\section{Control Variables}

Main Area of Work - The main areas in which an organization does work has a potential impact on sources of revenue. There are separate dummy variables for the following categories: Economic, Advocacy or Civic, Culture, Education, Environment, Health, Religious, and Capacity Building. Note that these are not mutually exclusive categories as a survey respondent could select as many or a little as applied to his or her organization. Based on Chang and 
Tuckman (1994), each of the main areas of work should have a positive and significant relationship with number of revenue sources. The relationship to the prioritization of earned income is expected to vary depending on the area of work as certain areas better lend themselves to a pay per service model.

Role of Organization - The role an organization plays also has a potential impact on the dependent variables as certain roles lend themselves better to generating earned revenue than others. The role an organization plays could also affect its ability to diversify through public grants, etc. As with the previous variable, this is represented by dummy variables for each of the categories in the survey. They include Community Development and Aid, Provider of Services, Buildings/Facilities, Advocacy, Support Services, and Grants or Financing. The hypothesized relationship in this paper is that organizations involved in providing services will be more likely to prioritize earned income over other groups. This variable in addition to Main Area of Work is believed to be sufficient enough to capture the public/private nature of an organization's activity and thus a separate variable was not constructed for this.

Geographic Deprivation Level - The geographic region where an organization is located could impact the dependent variables due to necessity of donations and public funding to achieve organizational goals. The dataset includes an index of multiple deprivation (IMD) for which more economically deprived geographic regions receive a higher score. Prior analysis suggests that a higher percentage of organizations in more deprived areas rely on public funding (Clifford, Rajme, Mohan, 2010). Thus, the hypothesized relationship with prioritization of earned income is negative. Organizations in more deprived areas are also likely to be less diversified as they are highly reliant on public funding. 
Scope of Work - This refers to the geographic scope in which an organization operates. This variable is 1 if the organization operates at the national or international level and 0 otherwise. Organizations that operate at the national level should have access to a larger pool of resources and thus a greater number of revenue sources. There is not likely a strong relationship with prioritization of earned income. This variable is included as an extension of the concept that geographic location has an impact on where an organization obtains its revenue from. Adequacy of Financial Resources - This variable refers to the confidence level that an organization has in its ability to meet its target goals. It is taken from the survey question "Did the organization believe it had adequate income in the last year to meet its main objective?" The variable equals 1 if the organization answered yes and 0 if the organization answered no. The hypothesized relationship is that more confident organizations will have more diversified revenue streams but will be less likely to prioritize earned revenue. As demonstrated by Chew (2008), a driving factor for third sector organizations to rely on earned income is the lack of funding from donations and the public sector. If an organization believes it has adequate existing resources, it is likely not motivated to generate its own revenue.

Annual Income - This serves as a proxy for organizational size. The variable is derived from banded data on income. The mean value for each of the bands is used to give a relevant estimation of magnitude and convert to a usable continuous variable. Overall, the expected relationship is that larger organizations will have less diversity in revenue sources as well as less of an incentive to generate earned revenue as proposed by Bowman, Keating, \& Hager (2007). 
It should be noted that any specific regional government tax policies or association membership data was not included in the survey. Thus, these two aspects are not present in the econometric analysis performed and the results should be considered in light of this fact.

\section{DESCRIPTIVE STATISTICS}

The following two tables present descriptive statistics for the sample of 41,894 organizations used for analysis.

\section{Table 1: Descriptive Statistics for Continuous Variables}

\begin{tabular}{|c|c|c|}
\hline Variable & Mean & Standard Deviation \\
\hline \multicolumn{3}{|l|}{ Dependent } \\
\hline $\begin{array}{l}\text { Number of Revenue Sources (How Many } \\
\text { Revenue Sources does an Organization Rely } \\
\text { Upon?) }\end{array}$ & 2.33 & 1.45 \\
\hline \multicolumn{3}{|l|}{ Independent } \\
\hline Income Level* & $£ 224,456$ & $£ 666,257$ \\
\hline Registration Year* & 1990 & 12.84 \\
\hline Geographic Area Level of Deprivation* + & 20.39 & 15.81 \\
\hline
\end{tabular}

* Original banded data was converted to a continuous variable by replacing each band with it's mean.

${ }^{+}$Level of Deprivation is derived from the index of matrial deprivation associated with the local area in which an organization is based. A higher score represents a more deprived geographic area 
Table 2: Frequency Distribution for Categorical Variables

\begin{tabular}{|c|c|c|}
\hline Variable & Frequency & Percent \\
\hline \multicolumn{3}{|l|}{ Dependent } \\
\hline \multicolumn{3}{|c|}{ Earned Revenue (Does Earned Revenue Account for } \\
\hline \multicolumn{3}{|c|}{$50 \%$ or More of an Organization's Total Income?) } \\
\hline Yes & 4,889 & $11.67 \%$ \\
\hline No/Missing & 37,005 & $88.33 \%$ \\
\hline \multicolumn{3}{|l|}{ Independent } \\
\hline \multicolumn{3}{|l|}{ Organizational Legal Form } \\
\hline$\overline{\text { Community Interest Company }}$ & 242 & $0.58 \%$ \\
\hline Industrial and Provident Society & 2,074 & $4.95 \%$ \\
\hline Registered Charity & 34,834 & $83.15 \%$ \\
\hline Company Limited by Guarantee & 4,744 & $11.32 \%$ \\
\hline \multicolumn{3}{|l|}{ Main Area of Work* } \\
\hline Economic & 13,029 & $31.10 \%$ \\
\hline Advocacy or Civic & 4,054 & $9.68 \%$ \\
\hline Cultural & 14,148 & $33.77 \%$ \\
\hline Education & 14,365 & $34.29 \%$ \\
\hline Environment & 1,746 & $4.17 \%$ \\
\hline Health & 7,448 & $17.78 \%$ \\
\hline Religious & 5,103 & $12.18 \%$ \\
\hline Capacity Building & 1,331 & $3.18 \%$ \\
\hline \multicolumn{3}{|l|}{ Role of Organization* } \\
\hline$\overline{\text { Community Development }}$ & 7,308 & $17.44 \%$ \\
\hline Service Provider & 11,231 & $26.81 \%$ \\
\hline Buildings and/or Facilities & 6,396 & $15.27 \%$ \\
\hline Advocacy & 10,846 & $25.89 \%$ \\
\hline Support Resources & 9,470 & $22.60 \%$ \\
\hline Grants or Financing & 6,439 & $15.37 \%$ \\
\hline \multicolumn{3}{|c|}{ Adequate Income (Did the Organization Believe that } \\
\hline \multicolumn{3}{|c|}{ it had Adequate Income in the Last Year?) } \\
\hline Yes & 21,339 & $50.94 \%$ \\
\hline No & 20,555 & $49.06 \%$ \\
\hline \multicolumn{3}{|c|}{ Scope of Operations (Does the Organization Operate } \\
\hline \multicolumn{3}{|c|}{ at the National or International Level?) } \\
\hline Yes & 7,464 & $17.82 \%$ \\
\hline No & 34,430 & $82.18 \%$ \\
\hline
\end{tabular}


The statistics in Tables 1 and 2 show that most TSO organizations rely on a little over two sources of revenue and that only $11.67 \%$ prioritized earned income as a primary source of revenue. It is also not surprising that registered charities make up a large portion of the sample given their traditional role in the third sector. The average income level of $£ 224,456$ is being pulled up by a small number of organizations that have very large budgets compared to the sample as a whole. In fact, $50 \%$ of organizations in the data set reported annual income of $£ 25,000$ or less. The Geographic Deprivation score is based on an index that ranges from zero to $75+$ and $63 \%$ of observations had a ranking below twenty. The other descriptive statistics provide an accurate picture of the remaining characteristics of the organizations in the sample. 


\section{RESULTS}

Table 3: Effect of Legal Registration Status on Number of Revenue Sources (OLS Regression)

\begin{tabular}{|c|c|c|c|}
\hline Variable & $\begin{array}{l}\text { Company Limited by } \\
\text { Guarantee as Baseline }\end{array}$ & $\begin{array}{c}\text { Registered Charity } \\
\text { as Baseline }\end{array}$ & $\begin{array}{c}\text { Industrial and } \\
\text { Provident Society as } \\
\text { Baseline }\end{array}$ \\
\hline \multicolumn{4}{|l|}{ Organizational Form } \\
\hline Community Interest Company & $\begin{array}{c}0.0485 \\
(0.0796)\end{array}$ & $\begin{array}{c}-0.363^{* * *} \\
(0.0782)\end{array}$ & $\begin{array}{c}0.0726 \\
(0.0826)\end{array}$ \\
\hline Industrial and Provident Society & $\begin{array}{l}-0.0241 \\
(0.0326)\end{array}$ & $\begin{array}{c}-0.435 * * * \\
(0.0288)\end{array}$ & \\
\hline Registered Charity & $\begin{array}{l}0.411 * * * \\
(0.0194)\end{array}$ & & $\begin{array}{l}0.435^{* * * *} \\
(0.0288)\end{array}$ \\
\hline Company Limited by Guarantee & & $\begin{array}{c}-0.411 * * * \\
(0.0194)\end{array}$ & $\begin{array}{c}0.0241 \\
(0.0326)\end{array}$ \\
\hline Constant & $\begin{array}{c}-0.0972 * * * \\
(0.0286)\end{array}$ & $\begin{array}{l}0.314 * * * \\
(0.0231)\end{array}$ & $\begin{array}{c}-0.121 * * * \\
(0.0367)\end{array}$ \\
\hline Observations & 41,894 & 41,894 & 41,894 \\
\hline Prob $>$ F & 0.0000 & 0.0000 & 0.0000 \\
\hline R-squared & 0.288 & 0.288 & 0.288 \\
\hline
\end{tabular}

Table 3 presents the results for the OLS regression of organizational form on number of revenue sources. The main variable of interest, community interest company, is significant only when compared to the registered charity baseline. Thus, there is no predictable difference in the amount of revenue sources that community interest companies rely upon compared to companies limited by guarantee or industrial and provident societies. However, the statistically significant results compared to registered charities are in direct conflict with the proposed hypothesis, as it appears that community interest companies rely on fewer revenue sources than registered charities. This may be striking, but it is also important to take note of the magnitude of the 
coefficient. While the results are statistically significant, a predicted difference of .369 revenue sources may not be material in the context of the real world since revenue sources only come in discrete whole numbers. A more thorough explanation is proposed when analyzing these results in combination with the results of the probit regression.

Table 4: Effect of Legal Registration Status on Prioritization of Earned Income (Probit Regression)

\begin{tabular}{|c|c|c|c|}
\hline Variable & $\begin{array}{l}\text { Company Limited by } \\
\text { Guarantee as Baseline }\end{array}$ & $\begin{array}{c}\text { Registered Charity } \\
\text { as Baseline }\end{array}$ & $\begin{array}{c}\text { Industrial and } \\
\text { Provident Society as } \\
\text { Baseline }\end{array}$ \\
\hline \multicolumn{4}{|l|}{ Organizational Form } \\
\hline Community Interest Company & $\begin{array}{c}0.547 * * * \\
(0.0908)\end{array}$ & $\begin{array}{l}1.069 * * * \\
(0.0891)\end{array}$ & $\begin{array}{c}0.387 * * * \\
(0.0941)\end{array}$ \\
\hline Industrial and Provident Society & $\begin{array}{c}0.160 * * * \\
(0.0377)\end{array}$ & $\begin{array}{c}0.681 * * * \\
(0.0334)\end{array}$ & \\
\hline Registered Charity & $\begin{array}{l}-0.522 * * * \\
(0.0248)\end{array}$ & & $\begin{array}{c}-0.681 * * * \\
(0.0334)\end{array}$ \\
\hline Company Limited by Guarantee & & $\begin{array}{l}0.522 * * * \\
(0.0248)\end{array}$ & $\begin{array}{c}-0.160 * * * \\
(0.0377)\end{array}$ \\
\hline Constant & $\begin{array}{l}-2.635^{* * *} \\
(0.0516)\end{array}$ & $\begin{array}{l}-3.157 * * * \\
(0.0479)\end{array}$ & $\begin{array}{c}-2.476^{* * *} \\
(0.0586)\end{array}$ \\
\hline Observations & 41,894 & 41,894 & 41,894 \\
\hline Prob > chi 2 & 0.0000 & 0.0000 & 0.0000 \\
\hline Pseudo R-squared & 0.181 & 0.181 & 0.181 \\
\hline \multicolumn{4}{|c|}{$\begin{array}{l}\text { This table displays the probit regression results for the independent variable of interest, organizational form, on the probability that an organization } \\
\text { will prioritize earned income. Control variables are not displayed here but can be found in appendix B. The regression was run three times, with a } \\
\text { different organizational form as the baseline in each case. The columns represent which baseline was used. Rows correspond to the regression } \\
\text { coefficients on each organizational form dummy variable compared to the baseline. Since this is a probit specification, the magnitude of the } \\
\text { coefficients should not be interpreted directly without some type of transformation. However, they can provide directional guidance in this form. } \\
* * * p<0.01, * * p<0.05, * \mathrm{p}<0.1\end{array}$} \\
\hline
\end{tabular}

Table 4 presents the results of the probit regression of organizational form on the probability that an organization prioritizes earned income. In this case, there are statistically significant results at the $99 \%$ confidence level that community interest companies are more 
likely to prioritize earned income as their primary revenue source than registered charities, companies limited by guarantee, or industrial and provident societies. While the coefficients cannot be interpreted directly as in an OLS regression, the direction of the coefficients supports the hypothesis that CIC's are more likely to prioritize earned income than other forms of TSO organizations. For interpretation of the coefficient size in the probit model, appendix $\mathrm{C}$ walks through an exercise where the effect of organizing as a CIC on the dependent variable can be estimated by assuming all other control variables are at their mean values. While this can only demonstrate the magnitude change in one scenario, it provides additional insight when comparing CIC's to registered charities, CLG's, and IPS's. In particular we see that if all control variables are held at their means, organization as a CIC results in an increase in the predicted probability of prioritizing earned income of $7.1 \%$ over IPS's, $11.0 \%$ over CLG's, and $27.7 \%$ over registered charities. Thus, the magnitude changes appear to be robust.

The results of the probit regression allow for a more nuanced understanding of the OLS results. While legal registration as a community interest company provides access to a more diverse array of revenue sources; it does not guarantee that organizations will actually take advantage of all of these sources. If organizations registered as CIC's prioritize earned revenue as their primary source of funding, they may actually have less of a need to draw upon other sources of revenue. This would result in revenue concentration rather than diversification. In fact, Chang and Tuckman (1994) show this relationship when comparing nonprofits that rely on commercial income versus those that rely primarily on donations.

One issue that remains is the relationship between organizational age and the two dependent variables of interest. Since both CLG's and IPS's did not have registration year 
information in the dataset, including organizational age as a control in the above analysis was not possible. Since all CIC's were registered in 2005 or later, it is entirely possible that the results are being driven largely by the newness of these organizations compared to other TSO's rather than the CIC organizational form itself. To investigate this issue, two additional regressions are run on a restricted sample of 4,226 CIC's and charities that have registration dates of 2005 or later.

Table 5: Effect of CIC Status on Diversification of Revenue Sources and Prioritization of Earned Income (New Organizations Only: Registration Post 2004)

\begin{tabular}{|c|c|c|}
\hline Variable & $\begin{array}{c}\text { Number of Revenue Sources } \\
\text { (OLS Regression) }\end{array}$ & $\begin{array}{c}\text { Prioritization of Earned Revenue } \\
\text { (Probit Regression) }\end{array}$ \\
\hline Community Interest Company & $\begin{array}{l}-0.247 * * * \\
(0.0843)\end{array}$ & $\begin{array}{l}1.158 * * * \\
(0.0976)\end{array}$ \\
\hline Constant & $\begin{array}{c}0.565^{* * * *} \\
(0.0790)\end{array}$ & $\begin{array}{l}-3.121^{* * * *} \\
(0.164)\end{array}$ \\
\hline Observations & 4,266 & 4,266 \\
\hline Prob $>$ F & 0.0000 & \\
\hline Prob > chi2 & & 0.0000 \\
\hline R-squared & 0.263 & \\
\hline Pseudo R-squared & & 0.184 \\
\hline
\end{tabular}

The similarities of the coefficients on the community interest company dummy variable to those in tables 3 and 4 provide support to the previously stated results and suggest that organizational newness may not necessarily be accounting for the observed relationship between CIC's and the dependent variables of interest. CIC's are predicted to have .247 less revenue sources than registered charities and have a higher probability of prioritizing earned income. 
However as time passes and more organizations form CIC's, additional research should be conducted to see if this relationship holds. Further research could also be conducted to see if the age of a CIC determines if the organization relies on more diverse revenue sources in earlier years until a sustainable profitability point is reached. Given the newness of all CIC's at this point in time, this analysis may have to wait.

\section{Control Variables}

The regression output results on the control variables can be seen in detail in appendices B and D. However, this section provides a brief discussion of main points of interest. Nearly all control variables display statistical significance in the primary models. In general, the Main Area of Work and Role of Organization dummies show a positive relation to number of revenue sources but the magnitudes tend to be small $(<1)$. One exception of note may be work in a religious area, which predicts more concentrated revenue sources. This is likely due to targeted funding from religious institutions or faith-based funding sources. Organizations focused on religious work also predicted a negative relationship with prioritization of earned income. The other exception to note is that organizations with the role of providing grants or financing also predicted more concentrated revenue sources and a negative relationship with prioritization of earned income.

The remaining control variables also convey useful information. As the income level of an organization increases, it tends to rely on more revenue sources as well as prioritize earned income. This is contrary to the hypothesized relationship and suggests that larger organizations 
either have access to a greater number of revenue sources or better realize the importance of revenue diversification for sustainability. The positive relationship with earned income suggests that larger organization may reach size limits with public and philanthropic funding, relying on earned income to grow. The scope of operations suggests that organizations operating at least at the national level have more concentrated revenue sources and are less likely to prioritize earned income. This is also contrary to the relationship hypothesized as it appears locally focused organizations may be able to better tap into a greater variety of small sources of funding as well as rely on earned income for operations. Organizations that are confident they have adequate financial resources show a positive relationship with the number of revenue sources but a negative relationship with the prioritization of earned income. These relationships are as predicted.

\section{POLICY IMPLiCATIONS AND CONCLUSIONS}

The results of the econometric analysis clearly support the notion that community interest companies use earned revenue as their primary source of financing at a high rate than other forms of legal organization. This is important, given that the community interest company legal structure was designed specifically to provide a better framework for social enterprises that often tend to rely more heavily on earned income. If the results showed otherwise, there may be concern that policy makers were not supporting social enterprise in the intended manner. The second finding, that community interest companies have fewer revenue sources than charities, is counter to the proposed hypothesis but not entirely shocking. As proposed previously, it is likely 
that as organizations rely more heavily on earned revenue, they become more financially selfsufficient and decrease their reliance on other revenue sources.

Policy makers in the UK and elsewhere should be able to look upon these results in generally favorable light. The community interest company legal structure is clearly facilitating revenue generating social enterprises just as the legislation was intended. The lack of a clear relationship between legal structure and revenue diversification warrants additional investigation, but should not be the source of any immediate concern. Structurally, the legislation creating the community interest company provides for access to a diverse range of funding sources. The extent that multiple sources are being used does not necessarily invalidate the specifications of the legal structure. Future research can further investigate the relationship between earned income and the reliance on a diverse array of revenue sources. It may also make sense to conduct this analysis again after the follow-up survey to the National Survey of Third Sector Organisations is completed this year. Given the newness of the CIC legislation, the nature and make-up of organizations opting for this legal form may change. It will be important to see if the results of this paper hold constant over time.

In this specific case study, the notion that organizational legal form has an effect on the decisions and behaviors that organizations undertake is supported. The decision to organize under a particular legal formation can alter the regulatory environment faced by an organization, making certain decisions regarding revenue sources both more feasible and preferable. Organizations are likely to consider this aspect of their operating environment in combination with the other aforementioned environmental, organizational, and activity characteristics during a decision-making process. A key distinction associated with the legal and regulatory 
environment though, is the influence that policy makers can exert to guide the decisions and behaviors of organizations. The structure of a particular legal and regulatory framework can provide access to or limit certain sources of funding as well as encourage or discourage earned revenue generation. Beyond the aspects examined in this paper, a legal and regulatory framework has the capability to influence decisions such as innovation, risk taking, and partnerships among other factors.

As other countries look to create a better legal and regulatory structure for social enterprises, the results of this analysis suggest that the model in the UK could provide a good starting point when designing such systems. In particular, U.S. states have been experimenting with creating a similar legal structure called an L3C. This is modeled from an existing for-profit form of legal organization but incorporates restrictions ensuring that a social goal is of primary focus. While the legislation in the United States is not identical to CIC's, they both were created with the purpose of facilitating social enterprise. This paper, for the first time, provides quantitative support backing the creation of these new forms of legal identity so that policy makers can proceed with confidence (but also cautiously). With further data gathering and analysis, new legislation supporting social enterprise can be made stronger and help to catalyze the force of change that social entrepreneurship is having in the world. 


\section{APPENDICES}

\section{Appendix A: Legal Form Overview}

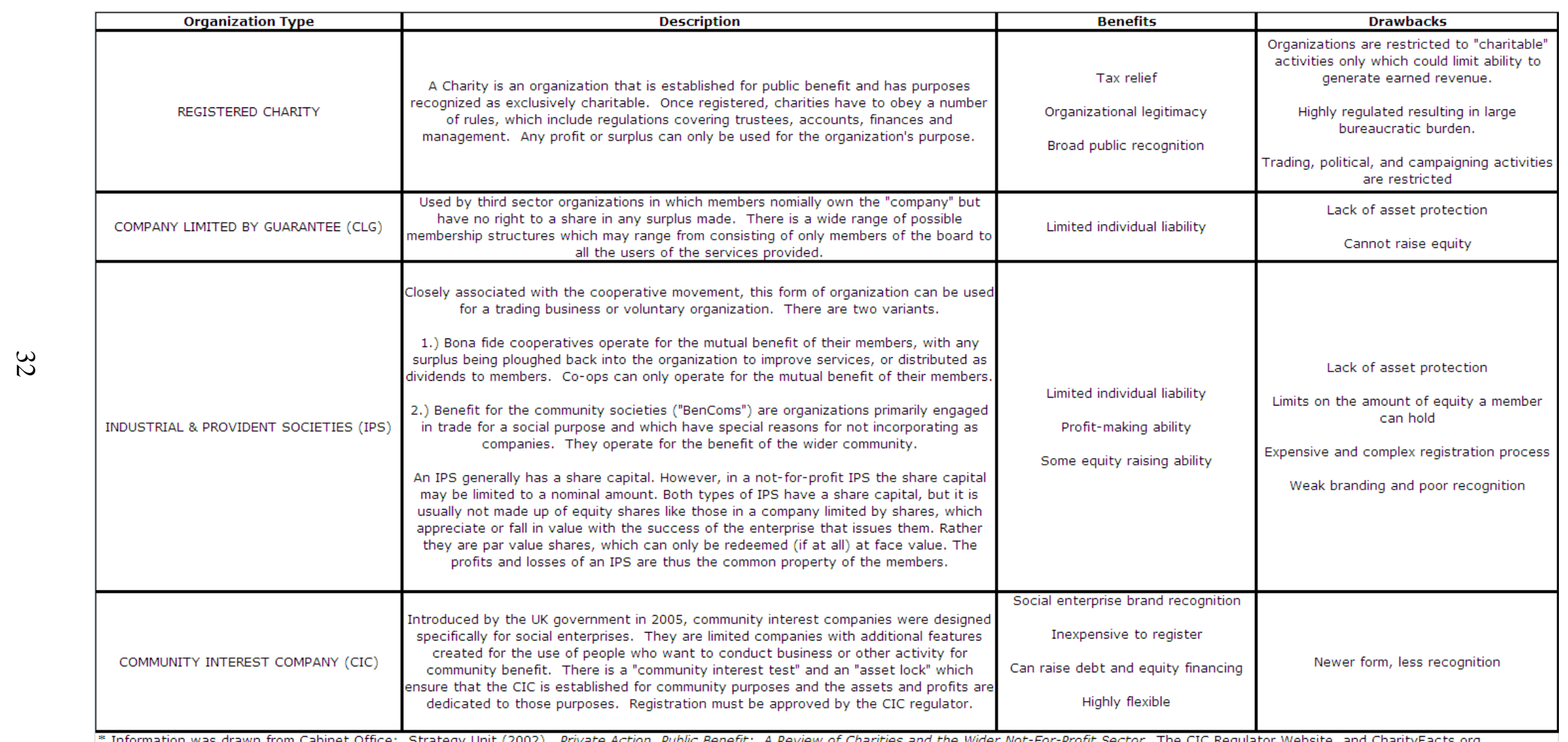


Appendix B: Control Variable Regression Coeffiencients (Full Model)

\begin{tabular}{|c|c|c|}
\hline Variable & $\begin{array}{c}\text { Number of Revenue Sources (OLS } \\
\text { Regression) }\end{array}$ & $\begin{array}{c}\text { Prioritization of Earned Revenue (Probit } \\
\text { Regression) }\end{array}$ \\
\hline \multicolumn{3}{|l|}{ Main Area of Work } \\
\hline Economic & $\begin{array}{c}-0.0656^{* * * *} \\
(0.0146)\end{array}$ & $\begin{array}{c}0.0223 \\
(0.0217)\end{array}$ \\
\hline Advocacy or Civic & $\begin{array}{c}0.185^{* * * *} \\
(0.0207)\end{array}$ & $\begin{array}{c}0.0234 \\
(0.0295)\end{array}$ \\
\hline Cultural & $\begin{array}{c}0.403^{* * * *} \\
(0.0137)\end{array}$ & $\begin{array}{c}0.135^{* * * *} \\
(0.0205)\end{array}$ \\
\hline Education & $\begin{array}{c}0.106^{* * * *} \\
(0.0131)\end{array}$ & $\begin{array}{c}0.0539 * * * \\
(0.0198)\end{array}$ \\
\hline Environment & $\begin{array}{c}0.271 * * * \\
(0.0298)\end{array}$ & $\begin{array}{l}-0.0114 \\
(0.0434)\end{array}$ \\
\hline Health & $\begin{array}{c}0.214 * * * \\
(0.0168)\end{array}$ & $\begin{array}{l}0.00130 \\
(0.0249)\end{array}$ \\
\hline Religious & $\begin{array}{c}-0.560 * * * \\
(0.0217)\end{array}$ & $\begin{array}{c}-0.297 * * * \\
(0.0385)\end{array}$ \\
\hline Capacity Building & $\begin{array}{c}0.312 * * * \\
(0.0349)\end{array}$ & $\begin{array}{c}0.193 * * * \\
(0.0455)\end{array}$ \\
\hline \multicolumn{3}{|l|}{ Role of Organization } \\
\hline Community Development & $\begin{array}{c}0.128 * * * \\
(0.0174)\end{array}$ & $\begin{array}{l}-0.0300 \\
(0.0260)\end{array}$ \\
\hline Service Provider & $\begin{array}{c}0.300 * * * \\
(0.0147)\end{array}$ & $\begin{array}{c}0.267 * * * \\
(0.0200)\end{array}$ \\
\hline Buildings and/or Facilities & $\begin{array}{c}0.127 * * * \\
(0.0176)\end{array}$ & $\begin{array}{c}0.381 * * * \\
(0.0244)\end{array}$ \\
\hline Advocacy & $\begin{array}{c}0.269 * * * \\
(0.0164)\end{array}$ & $\begin{array}{c}-0.0505^{* *} \\
(0.0249)\end{array}$ \\
\hline Support Resources & $\begin{array}{c}0.282 * * * \\
(0.0155)\end{array}$ & $\begin{array}{l}-0.0346 \\
(0.0232)\end{array}$ \\
\hline Grants or Financing & $\begin{array}{c}-0.478 * * * \\
(0.0178)\end{array}$ & $\begin{array}{c}-0.464 * * * \\
(0.0356)\end{array}$ \\
\hline \multicolumn{3}{|l|}{ Other Variables } \\
\hline Log Income Level & $\begin{array}{l}0.186^{* * * *} \\
(0.00205)\end{array}$ & $\begin{array}{l}0.161 * * * \\
(0.00418)\end{array}$ \\
\hline Adequate Income & $\begin{array}{l}-0.0232^{*} \\
(0.0122)\end{array}$ & $\begin{array}{c}-0.0606^{* * * *} \\
(0.0183)\end{array}$ \\
\hline Scope of Operations & $\begin{array}{c}-0.161^{* * *} * \\
(0.0163)\end{array}$ & $\begin{array}{c}-0.182^{* * * *} \\
(0.0269)\end{array}$ \\
\hline Georgraphic Deprivation Level & $\begin{array}{c}0.00272 * * * \\
(0.000395)\end{array}$ & $\begin{array}{c}0.00286 * * * \\
(0.000555)\end{array}$ \\
\hline
\end{tabular}

Standard errors in parentheses

*** $\mathrm{p}<0.01, * * \mathrm{p}<0.05, * \mathrm{p}<0.1$ 


\section{Appendix C: Probit Simulation}

Baseline: Company Limited by Guarantee

The Predicted Probability of an Organization

Prioritizing Earned Income with Control Variables

set to Mean Values.

\section{Predicted}

Probability when

$$
\mathrm{CIC}=0
$$

Predicted

Probability when

$\mathrm{CIC}=1$
0.0735

0.1832

\section{Baseline: Charity}

The Predicted Probability of an Organization

Prioritizing Earned Income with Control Variables set to Mean Values.

\section{Predicted}

Probability when

$$
\mathrm{CIC}=0
$$

0.0731

Predicted

Probability when

$$
\mathrm{CIC}=1
$$

0.3503
Difference

\section{Baseline: Industrial and Provident Society}

The Predicted Probability of an Organization

Prioritizing Earned Income with Control Variables set to Mean Values.

Predicted

Probability when

0.0736

$$
\mathrm{CIC}=0
$$

Predicted

Probability when

$\mathrm{CIC}=1$

Difference

0.2772


Appendix D: Control Variable Regression Coeffiencients (New Organizations Only: Registration post 2004)

\begin{tabular}{|c|c|c|}
\hline Variable & $\begin{array}{c}\text { Number of Revenue Sources (OLS } \\
\text { Regression) }\end{array}$ & $\begin{array}{c}\text { Prioritization of Earned Revenue (Probit } \\
\text { Regression) }\end{array}$ \\
\hline \multicolumn{3}{|l|}{ Main Area of Work } \\
\hline Economic & $\begin{array}{l}0.00830 \\
(0.0466)\end{array}$ & $\begin{array}{c}0.0133 \\
(0.0724)\end{array}$ \\
\hline Advocacy or Civic & $\begin{array}{c}0.181 * * * \\
(0.0588)\end{array}$ & $\begin{array}{c}0.0647 \\
(0.0863)\end{array}$ \\
\hline Cultural & $\begin{array}{c}0.434 * * * \\
(0.0457)\end{array}$ & $\begin{array}{l}-0.0710 \\
(0.0713)\end{array}$ \\
\hline Education & $\begin{array}{c}0.0317 \\
(0.0405)\end{array}$ & $\begin{array}{c}0.0553 \\
(0.0626)\end{array}$ \\
\hline Environment & $\begin{array}{c}0.247 * * * \\
(0.0903)\end{array}$ & $\begin{array}{l}0.0377 \\
(0.134)\end{array}$ \\
\hline Health & $\begin{array}{c}0.189 * * * \\
(0.0489)\end{array}$ & $\begin{array}{l}-0.0959 \\
(0.0746)\end{array}$ \\
\hline Religious & $\begin{array}{c}-0.641 * * * \\
(0.0635)\end{array}$ & $\begin{array}{c}-0.407 * * * \\
(0.116)\end{array}$ \\
\hline Capacity Building & $\begin{array}{c}0.323 * * * \\
(0.0941)\end{array}$ & $\begin{array}{c}0.133 \\
(0.126)\end{array}$ \\
\hline \multicolumn{3}{|l|}{ Role of Organization } \\
\hline$\overline{\text { Community Development }}$ & $\begin{array}{c}0.0734 \\
(0.0521)\end{array}$ & $\begin{array}{c}-0.189 * * \\
(0.0835)\end{array}$ \\
\hline Service Provider & $\begin{array}{c}0.301 * * * \\
(0.0460)\end{array}$ & $\begin{array}{c}0.212 * * * \\
(0.0667)\end{array}$ \\
\hline Buildings and/or Facilities & $\begin{array}{c}0.232 * * * \\
(0.0609)\end{array}$ & $\begin{array}{c}0.287 * * * \\
(0.0887)\end{array}$ \\
\hline Advocacy & $\begin{array}{c}0.224 * * * \\
(0.0483)\end{array}$ & $\begin{array}{c}0.0131 \\
(0.0738)\end{array}$ \\
\hline Support Resources & $\begin{array}{c}0.133^{* * * *} \\
(0.0450)\end{array}$ & $\begin{array}{c}0.0401 \\
(0.0690)\end{array}$ \\
\hline Grants or Financing & $\begin{array}{c}-0.440 * * * \\
(0.0575)\end{array}$ & $\begin{array}{c}-0.480 * * * \\
(0.120)\end{array}$ \\
\hline \multicolumn{3}{|l|}{ Other Variables } \\
\hline Log Income Level & $\begin{array}{l}0.160^{* * * *} \\
(0.00666)\end{array}$ & $\begin{array}{c}0.170^{* * * *} \\
(0.0142)\end{array}$ \\
\hline Adequate Income & $\begin{array}{c}0.0134 \\
(0.0399)\end{array}$ & $\begin{array}{l}-0.0771 \\
(0.0619)\end{array}$ \\
\hline Scope of Operations & $\begin{array}{c}-0.447 * * * \\
(0.0465)\end{array}$ & $\begin{array}{l}-0.256^{* * * *} \\
(0.0807)\end{array}$ \\
\hline Georgraphic Deprivation Level & $\begin{array}{c}0.00152 \\
(0.00115)\end{array}$ & $\begin{array}{l}0.000772 \\
(0.00169)\end{array}$ \\
\hline
\end{tabular}

Standard errors in parentheses

*** $\mathrm{p}<0.01,{ }^{* *} \mathrm{p}<0.05,{ }^{*} \mathrm{p}<0.1$ 


\section{REFERENCES}

Ashoka. (n.d.). Retrieved February 2011, from Ashoka: Innovators for the Public: www.ashoka.org

Banks, J. (1972). The Sociology of Social Movements. London: Macmillan.

Bornstein, D. (2004). How to Change the World: Social Entrepreneurs and the Power of New Ideas. London: Oxford University Press.

Bowman, H., Keating, E., \& Hager, M. (2007). Investment Income. In D. R. Young, Financing Nonprofits (pp. 157 - 181). Lanham, MD: Alta Mira Press.

Brooks, A. C. (2000). Public Subsidies and Charitable Giving: Crowding Out, Crowding In, or Both? Journal of Policy Analysis and Management , 451 - 464.

Cabinet Office: Strategy Unit. (2002). Private Action, Public Benefit: A Review of Charities and the Wider Not-For-Profit Sector. UK: Crown.

Chabotar, K. (1989). Financial ration analysis comes to nonprofits. Journal of Higher Education , $188-208$.

Chambre, S., \& Fatt, N. (2002). Beyond the liability of newness: Nonprofit organizations in an emerging policy domain. Nonprofit and Voluntary Sector Quarterly, 502 - 524.

Chew, C. (2008). Social Enterprise in Disguise? Towards hybrid forms of voluntary and charitable organizations in the UK. 12th Annual Conference of the IRSPM, Queensland University of Technology. Brisbane, Australia.

Clifford, D., Rajme, F. G., \& Mohan, J. (2010). How dependent is the third sector on public funding? Evidence from the National Survey of Third Sector Organisations. Birmingham: Third Sector Research Centre.

Dees, G. (2001). The Meaning of "Social Entrepreneurship". Kauffman Foundation.

Defourny, J., \& Nyssens, M. (2009). Social Enterprise in Europe: Recent Trends and Developments. EMES .

Department of Trade and Industry. (2002). Social Enterprise: A Strategy for Success. London: Crown. 
Derryck, D., \& Abzug, R. (2002). Lessons from crisis: New York City nonprofits postSeptember 11. Nonprofit Quarterly, 6 - 10.

Etzioni, A. (1973). The Third Sector and Domestic Missions. Public Administration Review, 314 $-323$.

Evans, L., \& Archer, S. (1968). Diversification and the reduction of dispersion: an empirical analysis. Journal of Finance, 761 - 767.

Fischer, R. L., Wilsker, A., \& Young, D. R. (2010). Exploring the Revenue Mix of Nonprofit Organizations: Does It Relate to Publicness? Nonprofit and Voluntary Sector Quarterly.

Fuller, R., \& Farrell Jr., J. (1987). Modern Investments and Security Analysis. New York: McGraw Hill.

Galbraith, J. (1977). Organizational Design. Reading, MA: Addison-Wesley.

Grameen Bank. (n.d.). Retrieved February 2011, from Grameen Bank: www.grameen-info.org Hulgard, L. (2010). Discources of Social Entrepreneurship - Variations of the Same Theme? EMES European Research Network .

Ipsos MORI Social Research Institute. (2009). National Survey of Third Sector Organisations. London.

Kimberly, J., Miles, R., \& Associates. (1980). The Organizational Life Cycle. San Francisco: Jossey-Bass.

Mandelson, P. (1997). Labour's Next Steps Tackling Social Exclusion. London: Fabian Society.

Nicholls, A. (2006). Social Entrepreneurship: New Models of Sustainable Social Change.

Oxford: Oxford University Press.

Office of the Third Sector, C. O. (2006). Social Enterprise Action Plan Scaling New Heights. London: Crown Copyright.

Okten, C., \& Weisbrod, B. (2000). Determinants of donations in private nonprofit markets. Journal of Public Economics, 255 - 272.

Pfeffer, J., \& Salancik, G. (1978). The External Control of Organizations. New York: Harper and Row. 
Regulator of Community Interest Companies. (n.d.). Community Interest Company Regulator. Retrieved February 2011, from http://www.cicregulator.gov.uk/

Reis, T. (1999). Unleashing New Resources and Entrepreneurship for the Common Good: A Scan, Synthesis, and Scenario for Action. Battle Creek: W.K. Kellogg Foundation.

Teach For America. (n.d.). Retrieved February 2011, from Teach For America: www.teachforamerica.org

The Nobel Peace Prize 2006. (2006). Retrieved April 5, 2011, from Nobelprize.org: http://nobelprize.org/nobel_prizes/peace/laureates/2006/

Thompson, J. (1967). Organizations in Action. New York: McGraw Hill.

Tuckman, H. P., \& Chang, C. F. (1994). Revenue Diversification Among Nonprofits. Voluntas , $273-290$.

White House. (n.d.). Office of Social Innovation and Civic Participation. Retrieved February 2011, from WhiteHouse.gov: http://www.whitehouse.gov/administration/eop/sicp

Wolk, A. (2007). Social Entrepreneurship and Government: A New Breed of Entrepreneurs Developing Solutions to Social Problems. In O. o. The Small Business Administration, The Small Business Economy: A Report to the President (pp. 151 - 203).

Young, D. R. (1985). Casebook of management for nonprofit organizations: Entrepreneurship and organizational change in the human services. New York: Haworth. 